Abstracta Iranica Abstracta Iranica

Revue bibliographique pour le domaine irano-aryen

Volume 28 | 2007

Comptes rendus des publications de 2005

\title{
Ismailis in Medieval Muslim Societies. London/New York, I.B. Tauris/The Institute of Ismaili Studies, 2005, 259 p.
}

Ève Feuillebois-Piérunek

\section{(2) OpenEdition}

1 Journals

Édition électronique

URL : http://journals.openedition.org/abstractairanica/12462

DOI : 10.4000/abstractairanica. 12462

ISSN : 1961-960X

Éditeur :

CNRS (UMR 7528 Mondes iraniens et indiens), Éditions de l'IFRI

\section{Édition imprimée}

Date de publication : 15 mai 2007

ISSN : 0240-8910

Référence électronique

Ėve Feuillebois-Piérunek, «Ismailis in Medieval Muslim Societies. London/New York, I.B. Tauris/The Institute of Ismaili Studies, 2005, 259 p. », Abstracta Iranica [En ligne], Volume 28 | 2007, document 265, mis en ligne le 18 septembre 2007, consulté le 25 septembre 2020. URL : http://

journals.openedition.org/abstractairanica/12462 ; DOI : https://doi.org/10.4000/abstractairanica. 12462

Ce document a été généré automatiquement le 25 septembre 2020.

Tous droits réservés 
Ismailis in Medieval Muslim Societies. London/New York, I.B. Tauris/The Institute of Ismaili Studies, 2005, 259 p.

Ève Feuillebois-Piérunek 
1 Le volume rassemble dix études sur l'ismaélisme, publiées entre 1992 et 2001 dans des revues scientifiques ou des volumes collectifs. Les introductions répétitives ont été enlevées, et la translittération unifiée.

2 Liste des articles et lieu de leur publication antérieure : 1. "Diversity in Islam » (in : Azam A. Nanji, ed, The Muslim Almanac, 1996); 2. «The Ismailis and Ismaili Studies» (nouveau)

3 Part I. The Early and Fatimid Phases : 3. "The Early Ismaili Movement and the Ismaili-Qarmati Schism» (Studia islamica, 77, 1993); 4. "The Ismaili Da'wa and the Fatimid Dawla (in: M. Barrucand, ed., L'Egypte fatimide, son art, son histoire, 1999); 5. "Sayyida Hurra: The Ismaili Queen of Yaman » (in : Gavin R.G. Hambly, ed., Women in the Medieval Islamic World, 1988).

Part II. The Nizari Phase : 6. "Historiography of the Early Nizari Ismailis in Persia » (Iran, Journal of the British Institute of Persian Studies, 30, 1992); 7. « Hasan-i Sabbâh and the Origins of the Nizari Ismaili $D a^{\prime} w a$ and State " (Mediaeval Isma'ili History and Thought, 1996); 8. "The Syrian Ismailis and the Crusaders: History and Myth » (in : Z. Hunyadi and J. Laszlovszky, eds., The Crusaders and the Military Orders: Expanding the Frontiers of Medieval Latin Christianity, 2001); 9. "Nasir al-din Tusi and the Ismailis» (in: N. Pourjavady et Z. Vesel, eds., Nasîr al-din Tûsi, philosophe et savant du XIIIe siècle, 2000); 10. «Ismaili-Sufi Relations in Post-Alamut Persia » (in : L. Lewisohn and D. Morgan, eds., The Heritage of Sufism, vol. III, Late Classical Persianate Sufism, 1999).

5 Part III. Aspects of Ismaili Thought : 11. «Intellectual Life Among the Ismailis » (in :

F. Daftary, ed., Intellectual Traditions in Islam, 2000).

INDEX

Thèmes : 7 . Islam

\section{AUTEURS}

ÈVE FEUILLEBOIS-PIÉRUNEK

Sorbonne Nouvelle - Paris III 